the disease occurs in epidemic form. The significance of a negative finding in a swab from a previous streptococcus carrier varies with the degree of skill with which the swab is taken and examined, and with the nature of the carrier state-whether symptomless or accompanied by catarrh or tonsillar hypertrophy. In the absence of any visible lesion a single competent negative swab should suffice.

Staphylococcus pyogenes aureus (recognized as pathogenic by the coagulase test) is the cause of pemphigus in infants, and multiple nasal carriers among maternity home staffs are its usual source. This subject was exhaustively dealt with in the Journal recently (see article by V. D. Allison and Betty C. Hobbs, July 5, p. 1).

\section{Over-possessive Women}

Q.-Is there any recognized psychosis or neurosis which corresponds to the ancient idea of "possession by evil spirits"? Having lately come across more than one pathologically possessive woman, I am tempted to formulate the following generalization: " $A$ possessive woman is a woman possessed." In extreme forms the condition would seem fraught with potential evil both to the patient and to those about her.

A.-Under "possession by evil spirits" the ancients must have understood a number of different syndromes, which certainly included epilepsy and hysteria, and probably others such as schizophrenia, mania, and melancholia. No modern concept exactly corresponds. It is true that the over-possessive woman can wreak havoc with the lives of others, especially husband and children. She is nearly always enabled to do so by meeting inadequate resistance from those who are "possessed." Her victims are commonly persuaded of the justice of her claims, but much may often be done by the trusted medical adviser to induce a healthier and more realistic attitude. $\mathrm{He}$ is in a particularly favourable position to do so if, as is often the case, she maintains her claims by representing herself as an invalid. It is rare that the "disease" is one of a single person; more usually it is a disordered relationship between two or several persons. Despite the malignant effects of such disorders, a psychotherapeutic attack is often possible.

\section{Chronic Prostatic Infection}

Q. -While in the Forces a male aged 24 years contracted a Bacterium coli urinary infection, starting with orchitis. No history of V.D. or risk. He has spent months in hospital, and has now been discharged as incurable on sulphathiazole $0.5 \mathrm{~g}$. thrice daily. He has been told that the infection is in the prostate and surgical removal might be the only cure. Shortly after stopping the drug the urine becomes foul and the patient feels ill. Can he with impunity continue to take the recommended dose of sulphathiazole indefinitely, and what alternative treatment do you suggest?

A. - It is a little pessimistic to regard a persistent infection of the prostate as being incurable. There are a few cases only which require surgical treatment in the way of perineal drainage for an abscess cavity in the parenchyma of the prostate. The great majority of such cases finally clear up with prolonged courses of prostatic massage, posterior irrigation, and the use of the sulphonamides. Sulphathiazole should not, of course, be continued indefinitely, but in separate courses of treatment resumed at intervals.

\section{Vaccination of a Nursing Mother}

Q.-If a nursing mother is vaccinated, what effects may this have on the child? Recently I vaccinated a mother, and within a week the baby had thirty or forty papules not unlike those of chicken-pox on its body. The mother blamed the vaccination.

A.-It is probable that following the development of immunity as a result of vaccination of the mother there will be some passive transfer of antibody to the infant. It would be possible for a vaccinated mother to infect her child with vaccinia as soon as a lesion appeared at the site of vaccination. The diagnosis of vaccinia in the child (or any vaccinated subject) can be readily confirmed in a virus laboratory by inoculation of material on to the chorio-allantoic membrane of the developing chick embryo.

\section{Sterilization of Syringes and Specula}

Q.-Is it possible to sterilize a spinal needle satisfactorily without an autoclave? What is the best solution for sterilization by prolonged immersion of syringes and specula for ordinary surgery use? I find that liq. borac. et formaldehyde (N.W.F.) ruins the hands if it touches them; and $5 \%$ liq. chloroxylenol. in surgical spirit forms a most adherent and obstinate precipitate.

A.- The best method is to place in a dry oven at $150^{\circ} \mathrm{C}$. for 1 hour. A less satisfactory alternative, but far better than the use of chemicals and subsequent rinsing in water, is boiling. A Record syringe cannot be sterilized chemically (for authority for this statement and general instructions on the subject see "The Sterilization, Use, and Care of Syringes," Medical Research Council War Memorandum No. 15, H.M.S.O., 4d.). A speculum should not be so difficult to sterilize, and could be freed of ordinary bacteria by any efficient disinfectant solution, including either of those mentioned, $2 \%$ lysol, or spirit. Disinfectants should not be condemned for such a purpose because they affect the skin; articles should be removed from them with forceps. Needless to say, for the patient's sake they need rinsing before use, and all such methods, properly carried out, are really more troublesome than boiling.

\section{NOTES AND COMMENTS}

Short-stay Hostel for the Aged and Infirm.-The old and infirm are often nursed at home by their own relatives. Old people who are becoming "difficult" may be more exacting in their demands on reiatives than they would be to strangers or nurses. $A$ recent and helpful development in connexion with this recurrent problem is the provision by the Red Cross of a hostel where elderly men and women, ambuiant or "bedridden, can stay for a fortnight or more, while their relatives have a rest or a holiday. Their own general practitioners can visit them as often as they wish, and their own callers may come on any afternoon, and on two evenings a week. The house, a gift to the Red Cross, is of moderate size, with a fairiy large garden, a lawn, and some fine trees. There are pleasant rooms, airy and sunny, with wards on the ground floor containing six beds apiece, and a comfortably furnished sitting-room with a wireless.

A fully qualified sister is in charge, with four helpers for day duty, and at night there are three on the premises, of whom one is a qualified nurse. In this hostel none of the staff lives in, but this is not a feature which need necessarily be copied elsewhere. At the same time it should be realized that many types of hospital, hostel, and institution are finding that the employment of nonresident staff is the only answer to the problem of recruitment. The running cost of this hostel varies from time to time, but it has usually worked out at rather more than $f 4$ per head a week, a moderate amount compared to the maintenance cost of hospitals. Visitors usually pay $£ 310$ s. a week, and the balance is found by the Red Cross. Schemes of this kind are obviously deserving of support, and it may be that every county should set up some similar scheme.

Correction.-Owing to a printer's error the name of Mr. Keith Vartan was unfortunately misspelt in the review of The 1946 Year Book of Obstetrics and Gynaecology in the Journal of Oct. 18 (p. 615).

\section{INCOME TAX}

All inquiries will receive an authoritative reply but only a selection can be published.

\section{Retirement-Subsequent Receipts}

A. D. asks whether he is liable for income tax on money earned before but coliected after retirement.

** A. D. has presumably been assessed in past years on the " cash receipt" basis. If, as is usually the case, such receipts have been year by year a fair index of the gross value of the bookings -and assuming that this is true of the last year before retirementno $\operatorname{tax}$ is due in respect of post-retirement receipts.

All communications with regard to editorial business should be addressed to THE EDITOR, BRITISH Medical JOURNAL, B.M.A. HOUSE, Tavistock SQUARE, LONDON, W.C.1. TELEPHONE: EUSTON 2111. TELFGRAMS: Aitiology, Westcent, London. ORIGINAL ARTICLES AND LETTERS forwarded for publication are understood to be offered to the British Medical Journal alone. Authors desiring REPRINTS should communicate with the Publishing Manager, B.M.A. House, Tavistock Square, W.C.1, on receipt of proofs. ADVERTISEMENTS should be addressed to the Advertisement Manager, B.M.A. House, Tavistock Square, London, W.C.1 (hours 9 a.m. to 5 p.m.) TELEPHONE: EUSTON 2111. TELEORAMS : Britmedads, Westcent, London. MEMBERS' SUBSCRIPTIONS should be sent to the SECRETARY of the Association. EUSTON 2111. TELEGRAMS: Medisecra, Westcent, London. B.M.A. Scotrish OFFICE: 7, Drumsheugh Gardens, Edinburgh. 